\title{
ASCEZĂ FILOSOFICĂ ŞI ASCEZĂ TEOLOGICĂ
}

\author{
George Remete*
}

Abstract: The philosophical and theological asceticism highlight very clearly the relevance between philosophy and theology. If the philosophical asceticism is an act purely intellectual and regards our performance, then the theological asceticism is a moral act which concerns the entity, referring to the person as a whole and the closeness with him.

Keywords: philosophy, theology, asceticism, morality, entity.

Pentru înțelegerea condiției morale a ființei și a cunoașterii este extrem de important să observăm că - precum cunoașterea și ființa însăşi - condiţia morală nu e numai dată ci trebuie și obţinută. După cum omul e ființă nu numai pentru că se pomenește existând ci și în măsura în care se autoconstruiește, tot astfel omul e ființă morală pentru că are dată această calitate dar şi pentru că şi-o construiește el însuși, prin decizie și efort permanent pentru bine. Experiența ne arată condiția istorică a omului ca foarte deficitară, grav denaturată și esenţial bolnavă. Această boală și denaturare, numită teologic păcat, grevează fundamental omul și poate fi constatată de orice cugetare onestă și riguroasă: am făcut această argumentare în vol. I al acestei lucrări și n-o repetăm aici. Așa după cum boala impune necesitatea regimului aspru, tot astfel condiția istorică impune ființei degradate și bolnave un regim sever de purificare și vindecare. De fapt, trebuie să spunem că, în lumea și în experiența noastră, condiția morală a omului se identifică atât de mult cu necesitatea ascezei încât putem afirma că numele adevărat al omului nu e „,condiţia” sau „ființa morală” ci condiţia sau ființa ,,ascetică”. Omul e ființă morală numai în măsura în care e ființă ascetică. Iar această definire nu e o colorare teologică, ci constatarea oricărei cercetări oneste și riguroase: nu numai ființa și cunoașterea teologică au nevoie de asceză ci ființa și cunoașterea cea mai simplă,

* PhD, Professor, Faculty of Orthodox Theology at „1 Decembrie 1918” University in Alba Iulia. 
cea „naturală”. Caracterul ascetic este criteriul autenticității oricărei cunoașteri și ființări, pe toată scara ființei, de jos până sus, de la minima creatură până la Dumnezeu. În această lume, ființa și cunoașterea sunt autentice numai prin asceză; fie sunt ascetice, fie sunt deficitare și bolnave: câtă asceză, atâta ființă! Tertium non datur.

Ştim că filosofia nu este interesată în mod deosebit de morală, pentru că socotește primordială ființa iar morala secundară. Pe de altă parte, gândirea aplicată obligă filosofia să recunoască statutul moral al ființei. Dar este de observat că, dacă recunoaște în principiu morala, filosofia nu este dispusă să accepte consecințele ei. Astfel, chiar dacă recunoaște necesitatea luptei pentru morală ca luptă pentru ființă, ea face alergie la ideea necesității ascezei: Morală morală, dar nici chiar așa! Chiar dacă acceptă sensul pozitiv al ascezei, nu acceptă necesitatea sau obligativitatea ei. Pentru filosofie, asceza este în cel mai bun caz lăudabilă, potrivită elitelor. De fapt, filosofia desparte morala de asceză, încât e dispusă să accepte morala refuzând în același timp asceza. Filosofia este în general vitalistă, iar aceasta a însemnat aproape totdeauna exaltarea forțelor și instinctelor primare și a biologiei omului. $\mathrm{Nu}$ încape îndoială că istoria filosofiei va conține până la sfârșit amândouă tendințele - atât cea vitalistă, cât și cea stoică - totuși, ni se pare că va rămâne dominantă tendința vitalistă. Filosofia socotește pozitive toate forțele și pornirile omului și nu înțelege de ce unele ar fi condamnabile. Pentru ea, naturalul omului, așa cum se înfățișează acum în istorie, este firea autentică și deplină a omului, încât ar fi ridicol și inautentic să-i reproșezi ceva. Înşirând amândouă tendințele, Heidegger arată că pentru mulți filosofi (pe care-i citează aprobator), tocmai eliberarea instinctelor și a pasiunilor este socotită drept naturalul omului; potrivit lui Nietzsche, homo naturae este acel om care face din trup firul călăuzitor al concepției sale despre lume ${ }^{1}$, și de aceea socotește că teologia creștină l-a denaturat, întrucât afirmă că această natură - lăsată în voia ei - aduce cu sine,

${ }^{1}$ M. Heidegger, Repere pe drumul gândirii, București, Editura Politică, 1988, p. 211. 
prin intermediul pasiunilor, ruina omului; tocmai de aceea, natura trebuie reprimată ${ }^{2}$.

Este extrem de important aici să observăm că punctul pe i al alergiei filosofiei față de teologie constă în reprimarea naturii, negarea sau forțarea firii, pe care cercetătorul o găsește într-adevăr în istoria spiritualității creștine occidentale. Dar dacă vrea să fie onest și riguros, el trebuie să caute în toate formele spiritualității creștine și va constata atunci indubitabil că în creștinismul răsăritean - în confesiunea ortodoxă - asceza nu înseamnă reprimarea, flagelarea sau negarea firii ci tocmai ,venirea în fire”, adică ordonarea sau raționalizarea forțelor, pornirilor, instinctelor și pasiunilor omului, pentru a le face din iraționale raționale, așa cum spune poetul român V. Voiculescu: puternicele-mi viții întoarse în virtuți („Ultimele sonete ...”, 26). Creștinismul este și el vitalist, dar vitalismul lui se deosebește esențial de cel filosofic sau biologic, așa cum se deosebește vederea unei femei ca soție față de vederea aceleiași femei ca amantă; și într-o situație și în cealaltă e prețuită și cultivată, dar numai în prima e cultivată responsabil și creator, pe când în a doua e în interes egoist și ne-creator.

Filosofia rămâne în general iluministă: ea recunoaște numai „luminile rațiunii” și nu vrea să fie condiționată de morală sau altceva. Refuzând însă asceza, ea arată că nu cunoaște condiția ființei și cunoașterii pe pământ, pentru că toate datele experienței ne arată lupta între firea omului și patimile iraționale, care o contrazic și o degradează: Mintea devine oarbă prin aceste trei patimi: prin iubirea de argint, prin slava deșartă și prin plăcere ... Cunoștința și credința, tovarășele firii voastre, nu sunt tocite prin nimic altceva ca prin acelea $^{3}$. Cercetătorul trebuie să înțeleagă că patimile nu sunt numai comportamente detestabile ci sunt degradare ființială, slăbind efectiv ființa și întunecând înțelegerea. Starea istorică nenorocită a firii umane impune necesitatea și urgența ascezei, aşa cum boala gravă impune urgent regimul sever: cancerul nu se tratează cu frecții

\footnotetext{
${ }^{2}$ Ibidem.

3 Sf. Marcu Ascetul, Despre legea duhovnicească, 101, în „Filocalia”, vol. I, Sibiu, 1947, p. 239.
} 
sau cu aspirină. În această lume, condiția morală deplină se atinge numai prin asceză. A fi moral înseamnă a fi organic-ascetic, pentru că înseamnă a alege condiția sacrificială ca viețuire. Numai aceasta este cunoașterea autentică, pentru că numai ea asigură sănătatea, adică autenticitatea şi deplinătatea ființei. Condiția ființei este organicitatea ascetică. Trebuie văzut că, deși ființa determină morala, totuși și morala face ființa: în definitiv, devii și ești ceea ce obişnuiești să faci tu din tine. Obiceiul tău e ființa ta.

Asceza este creatoare, pentru că păcatul sau patimile sunt deformarea firii și nu firea însăși. Ele sunt deformarea ... acelei Ordini care este dată făpturii de către Domnul, .. a acelei Structuri de profunzime ... a acelei Înțelepciuni în care se află rostul lumii ${ }^{4}$. Filosofia acuză asceza teologică de contrazicere și reprimare a rațiunii și a firii umane. Dar ideea ascezei ortodoxe este de a reprima bolile naturii umane și nu natura, tocmai pentru a-i revitaliza forțele. E vorba de a scăpa natura umană nu de firea ci de nefirea ei, de răul care-l posed $\breve{a}^{5}$. Ceea ce filosofic se numește degradare, slăbire și întunecare a firii umane, teologic înseamnă degradarea, slăbirea și întunecarea chipului lui Dumnezeu, a acelei imago Dei care constituie esența fiecărui om ca persoană sau creatură a lui Dumnezeu. Dacă asemănarea a devenit ne-asemănare, atunci ea înseamnă chiar înstrăinare și îndepărtare de Arhetipul ei. Teologic, patimile și păcatul înseamnă nu numai denaturare și îmbolnăvire ci și îndepărtare de Dumnezeu. Această realitate o exprimă exact sentința patristică atunci când afirmă: mie păcatele mi s-au făcut zid intunecat intre mine și Dumnezeu ${ }^{6}$. Iraționalitatea patimilor și contrazicerea firii de către ele nu sunt numai o direcție greșită și un comportament detestabil, ci sunt îmbolnăvire catastrofală. În cazul bolii grave soluția nu este îngrijirea cu paleative, cum încearcă filosofia (atunci când refuză asceza) ci optimismul ascezei care, deși

${ }^{4}$ P. Florenski, Stâlpul și Temelia Adevărului, Iași, Editura Polirom, 1999, p. 113.

5 Platon, Lysis, 217 b, în „Opere”, vol. II, București, Editura Știinţifică și Enciclopedică, 1976, p. 227.

${ }^{6}$ Patericul egiptean, „Avva Ammoi”, 3, Alba Iulia, Editura Episcopiei, 1990, p. 33. 
este severă, este singura care asigură vindecarea. Întrebarea nu este: „E gravă situația?” ci aceea care, auzind, i-a zis lui: Este pocăință, avva? Și i-a zis ei: Este! ${ }^{7}$. De aceea, rezolvarea înseamnă asumarea luptei și a suferinței, adică a sacrificiului. Se naște, există și dăinuie numai ceea ce (cine) dăruiește, iubește și se sacrifică. În acest sens afirmă Sfântul Maxim Mărturisitorul că toate se cer după cruce ${ }^{8}$, că taina Crucii este taina Ființei, iar păr. D. Stăniloae spune că ființarea este un dar pus sub semnul Crucii, adică al sacrificiului ${ }^{9}$.

Asceza este necesară nu numai ființei și cunoașterii teologice. Ea este condiția oricărei ființări și cunoașteri. Oricâte curente și tendințe ar înregistra, istoria filosofiei nu va scăpa de ea niciodată. În antichitate, Platon afirma că cei a căror viață a fost recunoscută de o deosebită sfințenie, aceștia sunt lăsați slobozi ... și se duc sus, in sălașurile cele pure ${ }^{10}$ iar în zilele noastre tocmai Heidegger, care în tinerețe și la maturitate aproba vitalismul lui Nietzsche, la bătrânețe a emis memorabila și definitiva sentință: Verzicht nimmt nicht!-Abținerea nu păgubește!. Gândirea laică poate accepta și ea că pasiunile sunt iraționale și degradează, încât $n$-am putut suporta mirosul urât al mâniei mele $e^{11}$ și că asceza purifică și iluminează, iar pentru aceasta e necesară conversia spirituală (metanoia), căci rodul și fapta pocăinței sunt cele care alungă neștiința și aduc cunoștința ${ }^{12}$. Gânditorul onest și riguros poate înțelege că asceza este absolut necesară în primul rând pentru cunoașterea de sine, căci chiar în aceasta și constă ea: că nici pe sine insuși nu se poate cunoaște cineva prin metodele distincției,

\footnotetext{
${ }^{7}$ Idem, „Avva Ioan Colov”, 43, p. 105.

${ }^{8}$ Sf. Maxim Mărturisitorul, Capetele teologice şi iconomice, suta întâi, 66-67, în „Filocalia”, vol. 2, Sibiu, 1947, p. 148-149.

${ }^{9}$ D. Stăniloae, Creația ca dar și Tainele Bisericii, în „Ortodoxia”, nr. 1/1976, pp. 10-29.

${ }^{10}$ Platon, Phaidon, 114 c, în „Opere”, vol. IV, București, Editura Științifică, 1983, p. 134.

${ }^{11}$ Paladie, Istoria lausiacă, „Despre Pahom”, București, Editura Institutului Biblic şi de Misiune al Bisericii Ortodoxe Române, 1993, p. 60.

${ }^{12}$ Sf. Simeon Noul Teolog, Discursuri teologice, I, în „Scrieri”, vol. I, Sibiu, Editura Deisis, 1998, p. 85.
} 
silogismului și analizei, dacă nu-și curăță mintea printr-o căință obositoare şi printr-o asceză susținută ${ }^{13}$. Înțelegerea înseamnă simplificare și unificare. Asceza înseamnă tocmai luminarea prin purificare și simplificare, așa cum a înțeles excepțional în antichitate gânditorul creștin Tertullian: Te chem ca martor pe tine cel simplu ... am nevoie de simplitatea ta $^{14}$.

De asemenea, filosoful poate înțelege că doar în virtute se manifestă tendința omului de a se transcende, prin faptul că biruie nu numai psihicul interior ci și închisoarea eului ${ }^{15}$, adică autocontrolul sau stăpânirea de sine. Filosoful nu se poate să nu știe că garanția ființei și a cunoștinței este libertatea gândului meu în pustie $^{16}$. Asceza este necesară nu numai pentru a atinge valori teologice, mistice sau supranaturale, ci și pentru autenticitatea cunoașterii în general, căci purificarea și centrarea ființială asigură suveranitatea cunoașterii de sine, încât omul vede în chip abundent lumina din sine ... când puterea sufletului domină patimile ${ }^{17}$. Filosoful trebuie să știe că omul este mai mult decât fenomenologie, că propriu lui este deschiderea nelimitată spre totalitatea cunoașterii și a ființei. De aceea, cunoașterea filosofică poate concluziona împreună cu cea teologică: Bună este ispitirea (asceza, n.n.)! Ea îl călește pe om ${ }^{18}$.

Dar sensul deplin al ascezei este numai cel teologic, căci între asceza filosofică și cea teologică este o diferență ca de la pământ la cer. Dacă filosofia se bazează pe înmulțirea gândurilor, teologia știe că gândul nu e neutru ci e bun sau rău, și de aceea

${ }^{13}$ Sf. Grigorie Palama, Tratatul III din Triada I, contra lui Varlaam, apud D. Stăniloae, „Viața și învăţătura sf. Grigorie Palama”, Sibiu, 1938, p. XXV.

${ }^{14}$ Tertullian, Despre mărturia sufletului, I, în „Apologeți de limbă latină”, col. „P.S.B.”, nr. 3, București, Editura Institutului Biblic şi de Misiune al Bisericii Ortodoxe Române, 1981, p. 119.

15 D. Stăniloae, Sensul ascezei monahale, Alba Iulia, Editura Reîntregirea, 2005 , p. 25.

${ }^{16}$ D. Tsamis, Patericul sinaitic, „Sisoe”, 25, Sibiu, Editura Deisis, 1995, p. 199.

${ }^{17}$ G. Palama, Tratatul III din Triada I contra lui Varlaam, ed.cit., p. XIX.

${ }^{18}$ Patericul egiptean, „Avva Pimen”, ed.cit., p. 269. 
preconizează un control și o adevărată luptă pentru luciditatea sau trezvia (népsis) duhovnicească. Dacă filosoful e fericit că are gânduri, teologul, dimpotrivă, vrea să scape de ele: Doamne, voi să mă mântuiesc și nu mă lasă gândurile ${ }^{19}$. Asceza creștină este o luptă atât de acerbă pentru controlarea gândurilor și pentru trezvie, încât lucrătorii ei afirmă că ne temem să vorbim intreolaltă, ca nu cumva să iasă vreo vorbă străină $\breve{2}^{20}$, unul dintre ei avea atâta trezvie în mintea sa, incât aproape la fiecare pas pe care-l făcea, de fiecare dată se oprea, cerceta gândul lui și-l întreba: Ce se întâmplă, frate, unde suntem? ${ }^{21}$ iar altul era mulțumit că la capătul ascezei de o viață putea să concluzioneze: Niciodată n-am lăsat în inima mea vreun gând care să mânie pe Dumnezeu ${ }^{22}$. Ca vigilență și autocontrol, trezvia a fost denumită de către asceți fixarea stăruitoare a gândului și oprirea lui la poarta inimii ${ }^{23}$ sau liniștea neîncetată a inimii de orice gând, care respiră și cheamă totdeauna, pururea și fără încetare, numai pe Hristos Iisus, Fiul lui Dumnezeu şi Dumnezeu ${ }^{24}$. Trezvia teologică nu înseamnă însă un simplu control logic sau psihologic al gândurilor, ci calificarea și purificarea lor. Ea nu este psihologie sau psihiatrie ci terapie duhovnicească, și se finalizează de fapt în vindecarea sufletească, de care sunt capabili numai duhovnicii ca terapeuți, la care veneau mulți mireni și monahi de pretutindeni și ișsi încredințau gândurile lor și se vindecau ${ }^{25}$.

Dar trezvia este numai începutul ascezei. Ea face posibilă cunoașterea duhovnicească, pentru că cunoștințta exactă a cuvintelor Duhului se descoperă ... numai acelora care ... curățindu-și mintea de funinginea patimilor, primesc cunoștința celor dumnezeiești ${ }^{26}$. Fără purificarea prin asceză, cunoașterea este

\footnotetext{
${ }^{19}$ Idem, „Avva Antonie”, 1, ed.cit., p. 7.

${ }^{20}$ Patericul sinaitic, ,Ammun”, ed.cit., p. 34.

${ }^{21}$ Idem, „Anonimi”, ed.cit., p. 44.

${ }^{22}$ Idem, „Siluan”, 1,6, p. 187.

${ }^{23}$ Idem, ,Isihie Preotul”, 4(6), p. 106.

${ }^{24}$ Ibidem, p. 105-106.

${ }^{25}$ Idem, ,Zenon”, 1, p. 96.

${ }^{26}$ Sf. Maxim Mărturisitorul, Răspunsuri către Talasie, 65, în „Filocalia”, vol. 3, Sibiu, 1948, p. 420.
} 
nu numai îngreuiată, deficitară sau întunecată ci chiar greșită și diabolică, pentru că ce este mai respingător decât cel care, fără să fi făcut pocăință și să se fi curățit mai înainte ... vrea să teologhisească ? $^{27}$. Pentru teologie, asceza nu este o simplă purificare, luminare sau ușurare a cunoașterii, ci însăși cunoașterea: A vorbi despre Dumnezeu este un lucru mare, dar este un lucru și mai mare a te curăța pentru Dumnezeu ${ }^{28}$.

Asceza este însă mai mult și decât cunoaşterea. Ea este luptă pentru purificarea, sfințirea și împlinirea ființială, în toate sensurile. Ea este însănătoșirea cunoașterii și ființei, ajungere ,în formă” sau împlinire, dar nu e simplu antrenament ci o adevărată luptă, dusă cu toate forțele, cu osteneală, primejdie și greutate, căci strâmtă este poarta și îngustă este calea care duce la viață și puțini sunt care o află (Matei 7,14). Ideea biblică a fost înțeleasă foarte bine și tradusă deplin de gândirea patristică, astfel: calea strâmtă şi îngustă aceasta este: să-şi silească cineva gândurile sale și să-şi taie voile pentru Dumnezeu ${ }^{29}$. Este evidentă imediat deosebirea acestei asceze de cea filosofică: fillosoful nu va ști niciodată ce înseamnă să-şi silească gândurile, va considera absurd și inutil să-și taie voile și n-o va face nici ,pentru sine”, cu atât mai puțin ,,pentru Dumnezeu”. Dar ascetul teolog ştie că numai prin această ,silire” și ,tăiere” poate ajunge la auto-control deplin, la stăpânire proprie și suveranitate. Iar aceasta nu poate fi înțeleasă decât prin experiență, prin biruirea deplină a patimilor, asemenea ascetului care se bucura și spunea plin de ardoare: Azi sunt rege. Mi-am stăpânit patimile ${ }^{30}$. Asceza ca luptă sau „război nevăzut” este luptă cu sine însuși, ca luptă împotriva iraționalităţii patimilor și egoismului, ca biruinţă a smereniei asupra mândriei. De aceea, ea are un nume clar și tranşant: pocăința. Există și asceză fără pocăință, dar tocmai aceasta este deosebirea între asceza filosofică și cea teologică. Pocăința înseamnă smerire totală,

${ }^{27}$ Sf. Simeon Noul Teolog, Discursuri teologice, 1, ed.cit., p. 84.

28 Sf. Grigorie de Nazianz, Discours, 32 („Oratio 32”), 12, în „Sources chrétiennes", nr. 318, Paris, Editions Cerf, 1985, p. 110.

${ }^{29}$ Patericul egiptean, „Avva Ammonà”, 11, p. 31.

${ }^{30}$ Idem, „Avva Iosif de la Panefo”, 10, p. 182. 
invocarea iertării și predarea totală lui Dumnezeu. Căci asceza nu este performanță a omului ca reușită proprie, pentru că reușita ei nu e decizie proprie ci decizie suverană a iubirii lui Dumnezeu ca răspuns la predarea iubitoare a omului, încât dacă din toată inima se va pocăi omul și nu va mai continua să facă păcatul, și în trei zile îl primește pe el Dumnezeu ${ }^{31}$.

Asceza este luptă reală, conștientă și voluntară, pentru că luptătorul identifică precis patimile, le cunoaște și le combate pe toate. De aceea, el este sfătuit deschis: ... când se apropie patimile ... Lasă-le să intre și luptă-te cu ele! $!^{32}$. Asceza este eroism și sacrificiu, pentru că cei care sunt ai lui Hristos Iisus și-au răstignit trupul împreună cu patimile și cu poftele (Gal. 5,24). Ea nu este antrenament și performanță psihică sau morală ci ființială, pentru că autenticitatea ei o arată numai înnoirea organică esențială: sufletul cunoaște că a primit Duhul Sfânt când i se vor opri patimile cele ce curg jos dintr-însul ${ }^{33}$. Autenticitatea ascezei o dă numai interdependența totală dintre sacrificiul omului și câștigarea harului: Dă sânge și ia Duhul! ${ }^{34}$. Asceza ca sacrificiu ia o formă concretă vizibilă: sângele alb, adică sudoarea și lacrimile în care se concretizează lupta de o viață întreagă a eroului, căci asceza este eroismul creștin.

Forma finală a ascezei este însă biruința, adică transfigurarea și sfințirea. Până la urmă, deosebirea esențială și finală între asceza filosofică și cea teologică este transfigurarea. Marii asceți au exprimat adeseori și fizic suveranitatea definitivă a ascezei. Deviza și premisa ascezei creștine a fost: Nu poți fi monah dacă nu devii ca un foc arzând $c$ u totul ${ }^{35}$. Dar aceasta nu era o premisă sau o țintă convențională ci un program realist de viață, verificat prin experiență, căci marii asceți au probat-o, precum Sfinții Arsenie cel Mare, Pimen și Sisoe cel Mare iar în zilele noastre păr. Arsenie

\footnotetext{
${ }^{31}$ Idem, „Avva Pimen”, 12, p. 168.

${ }^{32}$ Idem, „Avva Iosif de la Panefo", 3, p. 180.

${ }^{33}$ Idem, „Avva Longhin”, 6, p. 128.

${ }^{34}$ Ibidem.

${ }^{35}$ Idem, „Avva Iosif de la Panefo”, 6, p. 181.
} 
Boca, și de aceea invocarea realistă a ascetului era: Dă-mi harisma prieteniei cu focul! ${ }^{36}$. Numai această probă este finalul și garanţia ascezei creștine.

Dar asceza creștină se deosebește nu numai față de cea filosofică ci și față de ascezele teologice ne-creștine. Dacă în unele asceze ne-creștine, precum cea budistă, asceza este o performanță și o reușită umană, în creștinism ea presupune efortul omului dar reușita o asigură numai Dumnezeu, prin energia atotputernică sau harul Său. De asemenea, practicile ascetice ne-creștine se identifică de cele mai multe ori cu reprimarea trupului. E adevărat că unele practici creștine au căzut în această eroare, totuși trebuie observat că deviza tradițională a ascezei creștine a fost: noi nu ne-am invățat să fim omorâtori de trupuri, ci de patimi! ${ }^{37}$. Mai mult: în asceza creștină, nepătimirea (apátheia) nu constă nici măcar în omorârea părții pasionale, ci în re-direcționarea ei de la irațional la irațional, adică puternicele-mi viții întoarse în virtuți (V. Voiculescu, Ultimele sonete, 26), sau cum spune Sfântul Grigorie Palama: liber de patimi este ... cel care-și supune partea irascibilă și concupiscentă ... părții cugetătoare a sufletului, așa cum cei pătimași ișşi supun partea cugetătoare celei pasionale ${ }^{38}$. Dar unul din semnele deosebitoare cele mai evidente este faptul că în timp ce ascezele ne-creștine constituie o performanță cu efect scurt și adesea cu îmbolnăviri, regrese și degradări ființiale, asceza creștină este de cele mai multe ori discretă, ne-șocantă și constă nu în performanță ci în cumul ființial constant și definitiv. Asceza creștină nu este salt (cum sunt, adesea, cele ne-creștine) ci urcare din treaptă-n treaptă, consecventă, constantă, organică și definitivă.

Cumulul acesta organic și definitiv are un nume precis: nepătimirea, până la sfințire. Dacă asceza ne-creștină este performanță și spectacol, asceza ne-creștină este adesea anonimă sau modestă. În asceza ne-creștină forma depășește totdeauna conținutul

\footnotetext{
${ }^{36}$ Idem, „Avva Iacob”, 6, p. 183.

${ }^{37}$ Idem, „Avva Pimen”, 183, p. 190.

${ }^{38}$ Sf. Grigorie Palama, Codex Coislinianum gr. 100, f. 164 v - 165 r, apud D. Stăniloae, „Viața și învățătura Sf. Grigorie Palama”, ed.cit., p. 68.
} 
ființial, pe când în cea creștină conținutul excepțional poate fi purtat de o formă sau imagine minimă, până la anonimat. Asceza necreștină poate arăta performanțe uimitoare pe care și teologia creștină le poate recunoaște, pentru că și ne-creștinul (fiind „chipul lui Dumnezeu") are potențialități virtuale incredibile, în virtutea acestui chip, care pot fi actualizate. Dar aceste performanțe necreștine nu sunt legate necesar de nepătimire. Dimpotrivă, ascetul ne-creștin are în vedere în primul rând performanța, indiferent de condiția morală; ea poate fi deficitară, iar după consumarea performanței ascetul cade adesea într-o condiție morală degradată. Pentru ascetul creștin dimpotrivă, primordială și esențială este nepătimirea (ca și condiție morală deplină), iar performanța, indiferent că apare sau nu, este de importanță secundară. Chiar dacă nepătimirea se identifică uneori cu performanța, ascetul creștin n-o caută, n-o dorește și vrea totdeauna s-o ascundă. Pentru ascetul creștin, performanță nu este „performanța” ci însăși nepătimirea: Haina de nuntă este nepătimirea sufletului rațional care s-a lepădat de poftele lumești ${ }^{39}$.

O altă deosebire între asceza creștină și cea ne-creștină este aceea că asceza creștină constă în lupta cu sine însuși, cu patimile proprii și nu cu alții, cu lumea sau cu ființa. Des-pătimirea nu este negarea pasiunii ci a patimei: ea combate pornirile iraționale, nu energiile vitale fundamentale sădite de însuși Dumnezeu în firea omului. Dușmanul, adversarul sau concurentul este numai patima proprie, și nu ceilalți sau lumea. Ascetul ne-creștin, chiar dacă depune un efort excepțional pentru stăpânirea patimilor, o face nu pentru despătimirea definitivă ci numai pentru atingerea performanței, indiferent de consecințele morale ulterioare; lui îi este indiferent dacă după reușita performanței redevine un pătimaș, mai dominat decât înainte. Ascetul creștin știe că dacă ai depăşit patimile stăpânești totul, iar dacă nu le-ai depăşit chiar „stăpânirea” totului este iluzorie. Nu există decât o singură victorie: asupra ta însuți.

${ }^{39}$ Evagrie Ponticul, Capete despre deosebirea gândurilor, 22, în „Filocalia”, vol. 1, Sibiu, 1947, p. 66. 
O deosebire extrem de importantă este aceea că în asceza necreștină, indiferent cât de mari, spectaculoase, puternice sau marcante sunt performanțele, acestea nu sunt definitive și nu se constituie într-o reușită ființială definitivă. Indiferent că durează mai mult sau mai puțin, performanțele dispar relativ repede, nu rămâne nimic din ele și nu se concretizează într-o fiinţialitate superioară stabilă. Asceza creștină însă, indiferent că arată sau nu performanțe, are în vedere și se constituie principial într-o ființialitate superioară, transfigurată și stabilă, chiar definitivă. Semnul nepătimirii nu e performanța ci cumulul ființial stabil sau câștigarea stabilității definitive: Sufletul curățit prin plinătatea virtuților face rânduiala minții neclintită și destoinică să primească starea căutată $\breve{a}^{40}$. Cunoașterea și ființa autentică se certifică prin stabilitatea definitivă.

În sfârșit, deosebirea finală dintre asceza creștină și cea necreștină, subliniată de toți misticii creștini, este dobândirea Duhului Sfânt. Toate ascezele și toate misticile țintesc o cunoaștere și o condiţie superioară, transfigurată sau duhovnicească. Cercetătorul riguros poate să constate însă faptul extrem de interesant că asceza creștină - deși dorește să atingă viaţa duhovnicească sau transfigurarea - nu o consideră scop în sine, ci mijloc. Ea poate fi scop în sine numai în ascezele ne-creștine. Ascetul creștin nu este însă impresionat și nu se mulțumește cu nepătimirea și nici chiar cu transfigurarea. Scopul lui este PersoanaDumnezeu, Dumnezeu și numai Dumnezeu, adică apropierea, intimitatea sau unirea cu Dumnezeu, pentru că aceasta le conține pe toate iar fără ea toate celelalte se relativizează. Cercetătorul are datoria să constate că toată tradiția ascetică și mistică creștină - de la cea biblică și patristică, de la misticii pustiei și cei isihaști până la Sfântul Serafim de Sarov, Sfântul Siluan Athonitul, păr. Sofronie Sacharov și alții - au subliniat tranșant această convingere, premisă și țintă.

${ }^{40}$ Idem, „Capete despre rugăciune”, 2, ed.cit., p. 75. 